\title{
Malignant Transformation in Mature Cystic Teratomas of the Ovary: Case Reports and Review of the Literature
}

\author{
ANGIOLO GADDUCCI ${ }^{1}$, SABINA PISTOLESI ${ }^{2}$, MARIA ELENA GUERRIERI ${ }^{1}$, STEFANIA COSIO ${ }^{1}$, \\ FRANCESCO GIUSEPPE CARBONE ${ }^{2}$ and ANTONIO GIUSEPPE NACCARATO ${ }^{2}$ \\ ${ }^{1}$ Department of Experimental and Clinical Medicine, \\ Division of Gynecology and Obstetrics, University of Pisa, Pisa, Italy; \\ ${ }^{2}$ Department of New Technologies and Translational Research, \\ Division of Pathology, University of Pisa, Pisa, Italy
}

\begin{abstract}
Malignant transformation occurs in 1.5-2\% of mature cystic teratomas (MCT)s of the ovary and usually consists of squamous cell carcinoma, whereas other malignancies are less common. Diagnosis and treatment represent a challenge for gynecologic oncologists. The preoperative detection is very difficult and the diagnostic accuracy of imaging examinations is uncertain. The tumor is usually detected post-operatively based on histopathologic findings. This paper reviewed 206 consecutive patients who underwent surgery for a histologically-proven MCT of the ovary between 2010 and 2017. Malignant transformation occurred in $3(1.5 \%)$ of them, and consisted of squamous cell carcinoma in one, type 2 papillary renal carcinoma in one, and papillary thyroid carcinoma in another one. The paper reported the clinical, radiological and histological features of these cases and reviewed the literature data on the treatment options.
\end{abstract}

Mature cystic teratoma (MCT) of the ovary has an incidence of approximately 1.2-14.2 cases per 100,000 women per year and accounts for $10-20 \%$ of all ovarian tumors $(1,2)$. Laparoscopic salpingo-oophorectomy with an endoscopic retrieval bag is the standard treatment in postmenopausal women and in perimenopausal women with a large teratoma, whereas laparoscopic cystectomy can be a rational option in younger women (3). Malignant transformation occurs in 1.5$2 \%$ of the cases and usually consists of squamous cell

Correspondence to: Angiolo Gadducci, Department of Experimental and Clinical Medicine, Division of Gynecology and Obstetrics, University of Pisa, Via Roma 56, Pisa, 56127, Italy. Tel: +39 50992609, Fax: +39 50553410, e-mail: a.gadducci@med.unipi.it

Key Words: Teratoma of the ovary, squamous cell carcinoma, papillary renal cell cancer, thyroid carcinoma, struma ovarii, surgery. carcinoma (4-8). Other less frequent malignancies include mucinous carcinoma (8-10), adenocarcinoma arising from the respiratory ciliated epithelium (11), melanoma (9), carcinoid (8), thyroid carcinoma (8, 10, 12-15), oligodendroglioma (10) and sarcoma (10).

The diameter of a squamous cell carcinoma arising in an ovarian MCT ranges from 9.7-15.6 cm $(1,4-8,16,17)$ and median age of patients is approximately 55 years $(1,16)$, whereas the size of thyroid carcinoma in an MCT ranges from 5 to $20 \mathrm{~cm}$ and the median age of patients is about $42-$ 45 years $(12,15)$. The preoperative detection of malignant transformation is very difficult and the diagnostic accuracy of ultrasound, magnetic resonance imaging and computed tomography (CT) is uncertain (18-23). Malignancy is usually diagnosed post-operatively based on histopathologic findings $(6,8,13,15,24)$.

The standard primary treatment of squamous cell carcinoma within an MCT of the ovary should consist of bilateral salpingo-oophorectomy, total hysterectomy and comprehensive surgical staging in early disease and optimal cytoreductive surgery in advanced disease $(1,6,25)$. Patients with surgical stage Ia tumor can undergo observation alone, whereas chemotherapy is warranted for those with more advanced disease $(4,16,17,25,26)$. The combination of paclitaxel and carboplatin is the most frequently used regimen, although chemotherapy seems to be less effective in this malignancy compared to the common epithelial ovarian cancers $(16,21,25-27)$. The role of radiotherapy or chemoradiotherapy is debated $(1,5,6,16,26-29)$.

Papillary and follicular carcinoma are the most frequent types of thyroid carcinoma occurring in an ovarian MCT (14). The diagnostic criteria for papillary carcinoma are similar to those of cervical thyroid gland carcinoma and are based primarily on nuclear and architectural features, whereas the diagnosis of follicular carcinoma is mainly based on infiltration into the surrounding ovarian tissues and vascular invasion besides detection of metastasis. Although 
the management of thyroid carcinoma in MCT is controversial, many authors have suggested that treatment should be similar to the one used for the differentiated carcinoma of the thyroid gland, and that, following surgical excision of the ovarian tumor, the patient should undergo thyroidectomy, iodine $[\mathrm{I}]^{131}$ ablation, and levothyroxine suppressive therapy $(12,15,30)$.

In this paper, 3 cases of malignant transformation in MCTs of the ovary are reported.

\section{Case Description}

This paper reviewed 206 consecutive patients who underwent surgery for a histologically proven MCT of the ovary between 2010 and 2017. The median age of patients was 39 years (range $=9-83$ years). Malignant transformation occurred in $3(1.5 \%)$ of them and consisted of squamous cell carcinoma in one (a), type 2 papillary renal carcinoma in one (b), and papillary thyroid carcinoma in another one (c).

a) A 55-year-old, postmenopausal, gravida 4, para 2 woman was admitted to the hospital for the onset of abdominal swelling. She took levothyroxine for hypothyroidism and valproic acid for depression. Gynecological examination revealed a huge, mobile pelvic mass, and abdominal-pelvic CT scan showed an $18 \times 11 \mathrm{~cm}$ complex ovarian mass which had no apparent cleavage plan with the uterus and which displaced adjacent organs. Its content was mainly fluid, with a small solid area in the lower part and some vascularized papillary projections. There were no enlarged retroperitoneal nodes, no peritoneal implants, and no suspected lesions in the liver, pancreas, spleen, and kidneys. Chest X-ray was unremarkable and serum CA 125 was $19 \mathrm{U} / \mathrm{ml}$. Laparoscopy detected a large, rounded, smooth mass involving left ovary, whereas uterus and right ovary were grossly normal and pelvic peritoneum, para-colic gutters, small and large bowel, mesentery, liver, spleen, and diaphragmatic surfaces were free of macroscopic lesions. Left salpingo-oophorectomy was performed, and the adnexum was recovered with an endoscopic retrieval bag and sent for frozen sections which showed a squamous cell carcinoma within an MCT. Then, the patient underwent peritoneal washing, total hysterectomy, right salpingooophorectomy, infra-colic omentectomy, and systematic pelvic and aortic lymphadenectomy. Macroscopically, the left ovarian tumor measured $19 \times 17 \times 7 \mathrm{~cm}$, with whitish, smooth external surface, widely necrotic wall with hair, and inner yellowish content. The definitive histopathological examination revealed an invasive poorly differentiated, keratinizing squamous cell carcinoma arising in an MCT and approaching to the external ovarian surface (Figure 1). Immunostaining for p16 was negative. Adjacent areas of squamous cell carcinoma in situ were detected, whereas there was neither lymph vascular space involvement nor perineural invasion. The left fallopian tube, right ovary, right fallopian tube, omentum and pelvic and para-aortic nodes as well as peritoneal cytology were negative. FIGO stage was Ia. The patient is currently undergoing adjuvant chemotherapy with paclitaxel $175 \mathrm{mg} / \mathrm{m}^{2}$ plus carboplatin area under the curve (AUC) 5 every 3 weeks. Clinical and ultrasound evaluation after the fifth cycle of chemotherapy showed no evidence of disease.

b) A 48-year-old, premenopausal, gravida 1, para 0 woman presented with a history of abdominal pain. She had undergone myomectomy for a uterine fibroid one year before. She took levothyroxine for Hashimoto's thyroiditis, venlafaxine for depression, and noretisterone acetate for abnormal uterine bleeding. Gynecological examination detected a small, tense elastic cyst in the left ovary, and pelvic and transvaginal ultrasound showed that this lesion was multilocular solid with International Ovarian Tumor Analysis (IOTA) color score 3-4. Right ovary contained a corpus luteum, uterine body and cervix were normal, and endometrial lining was thin. Chest X-ray and cervical smear were normal and serum CA 125 was $42.8 \mathrm{U} / \mathrm{ml}$.

Laparoscopy evidenced a 3-4 cm smooth cyst of the left ovary, whereas uterus and right ovary were grossly normal and pelvic peritoneum, para-colic gutters, small and large bowel, mesentery, liver, spleen, and diaphragmatic surfaces were free of macroscopic lesions. Left salpingo-oophorectomy was performed, the adnexum was removed with an endoscopic retrieval bag, and the definitive histological examination revealed a type 2 papillary renal carcinoma with neuroendocrine features within an MCT (Figure 2). The neoplasia, measuring $1.5 \mathrm{~cm}$ in the largest diameter, presented tubular-papillary architecture, severe atypia, mitotic count $=5 / 10$ High Power Field (HPF), subepithelial deposits and foamy macrophages. Immunostaining was positive for CK7, CAM5.2, Ber-EP4, EMA, CD56, NSE and estrogen receptor (ER) (focal) and negative for CK20, thyroglobulin, TTF-1, CA19.9, S-100, GCDFP-15, calretinin, WT-1 and progesterone receptor (PR). No tumor was present on ovarian surface as well as in fallopian tube. A positron emission tomography (PET)/CT scan performed 3 months after surgery was negative. The patient, who refused total hysterectomy and right salpingooophorectomy, is currently undergoing periodical follow-up and is free of disease 16 months after surgery.

c) A 44-year-old, premenopausal, gravida 0 , para 0 woman had previously undergone thyroidectomy followed by $\mathrm{I}^{131}$ ablation and levothyroxine suppressive therapy for a papillary carcinoma of the thyroid gland. Six months later routine serum thyroglobulin assay showed raised antigen levels $(674 \mathrm{ng} / \mathrm{ml})$. Whole-body radioiodine scintigraphy evidenced a focal, intense $\mathrm{I}^{131}$ uptake in the right pelvis suggestive of the presence of ectopic thyroidal tissue, and a transvaginal ultrasound detected a $7 \times 3 \mathrm{~cm}$, multilocular solid, vascularized round mass in the right ovary, a $1.5 \mathrm{~cm}$ 


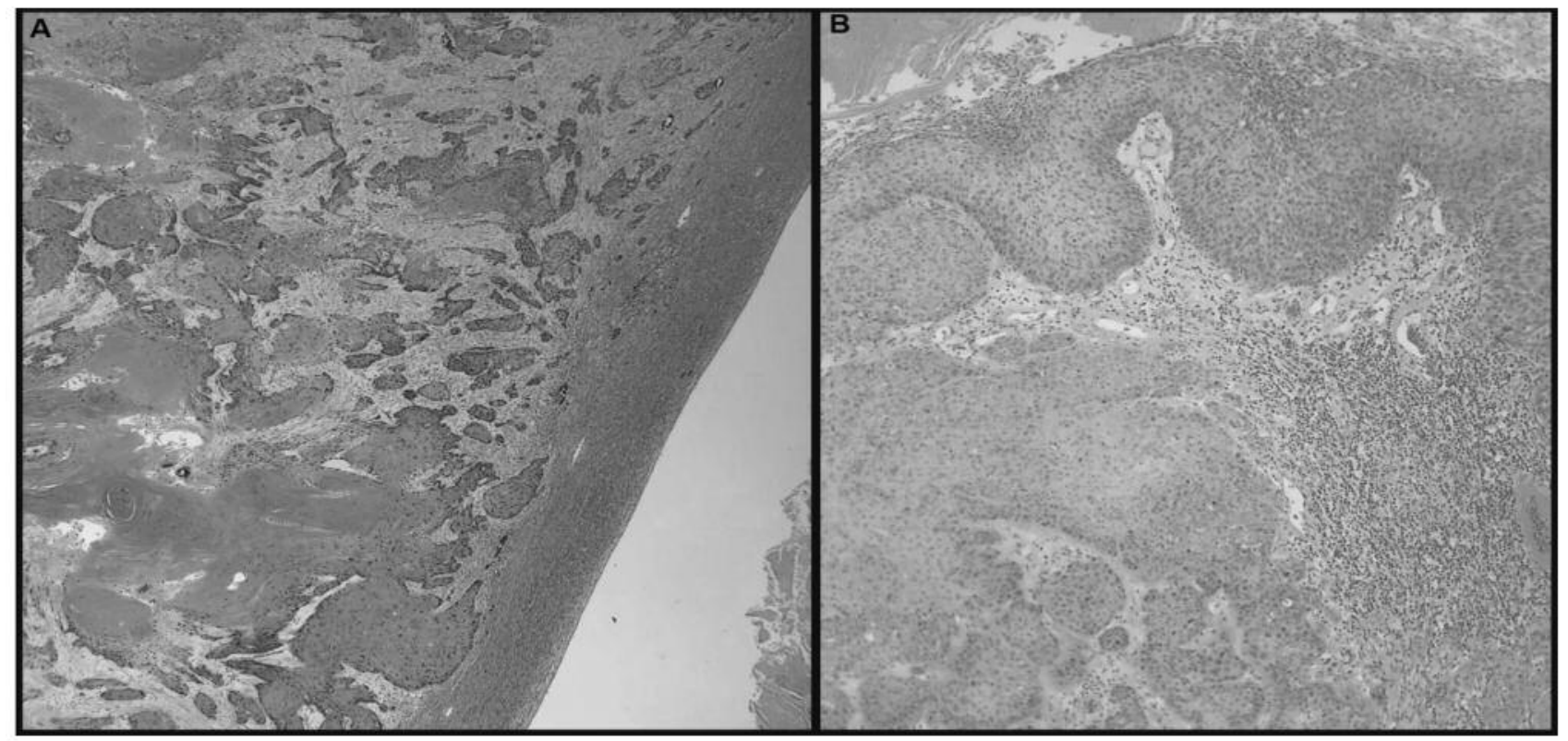

Figure 1. Squamous cell carcinoma within a mature cystic teratoma of the ovary. A: Squamous cell carcinoma arising in a mature cystic teratoma of the ovary. Invasive squamous cell nests are surrounded by ovarian stroma; keratin formation is detectable in some nests. B: Features similar to a squamous cell carcinoma in situ are present in the epithelium near the invasive component.

intramural myoma in the uterine fundus, and a normal left ovary. CT scan revealed a $7 \times 5 \times 6 \mathrm{~cm}$ multilocular, complex mass with a solid portion and internal calcification in the right ovary, whereas peritoneal surfaces, retroperitoneal lymph nodes, and upper abdomen organs were unremarkable. Radioiodine scintigraphy and CT findings suggested the presence of a struma ovarii. Chest X-ray and cervical smear were normal. Laparoscopy detected a 5-cm mixed cystic and solid mass of the right ovary, where uterus and left ovary were apparently normal. The inspection of pelvic and abdominal peritoneum, ileum, colon, liver, spleen, and diaphragmatic surfaces failed to detect any macroscopic lesions. Right salpingo-oophorectomy was performed and the surgical sample was recovered with an endoscopic retrieval bag. The definitive histological examination showed a $0.7 \mathrm{~cm}$, well differentiated papillary thyroid carcinoma within a struma ovarii (Figure 3). The residual ovarian parenchyma contained a necrotic nodule with calcification and corpora albicans. The patient, who underwent periodical serological, clinical and ultrasound examinations, is currently free of disease 52 months after surgery.

\section{Discussion}

Malignant transformation occurs in $1.5-2 \%$ of the MCTs of the ovary, and usually consists of squamous cell carcinoma (4-8). Regarding the patient with such malignancy in our series, age (55 years) and tumor diameter $(19 \times 17 \mathrm{~cm})$ matched with the median values reported in the literature ( 1 , $4-8,16,17)$. The preoperative evaluation was not exhaustive and the squamous cell carcinoma was first detected at intraoperative frozen sections. Immunostaining for p16 was negative, which did not support the hypothesis that human papillomavirus (HPV) is a risk factor for this malignancy. Very few and conflicting data are available in the literature as regarding HPV detection and p16 expression in squamous cell carcinoma arising in MCTs of the ovary (31-34). In agreement with most authors $(1,6,25)$, the patient underwent bilateral salpingo-oophorectomy, total hysterectomy and comprehensive surgical peritoneal and retroperitoneal staging, and the definitive histological examination of surgical specimens revealed that FIGO stage was Ia. Although some authors $(26,27)$ suggest observation alone in this clinical setting, we chose to give adjuvant paclitaxel/ carboplatinbased chemotherapy, after exhaustive discussion with the patient herself who preferred to receive a prophylactic treatment.

Papillary renal cell carcinomas account for $10-20 \%$ of all renal cell cancers (35). Based on cytologic and histologic criteria, Delahunt et al. (36) divided these tumors into two morphologic groups, type 1 and type 2, differing in stage, grade and prognosis. Type 2 tumors have a more aggressive biological behavior (37). In any case, patients with stage I papillary renal cell carcinoma do not need adjuvant treatment (38). 


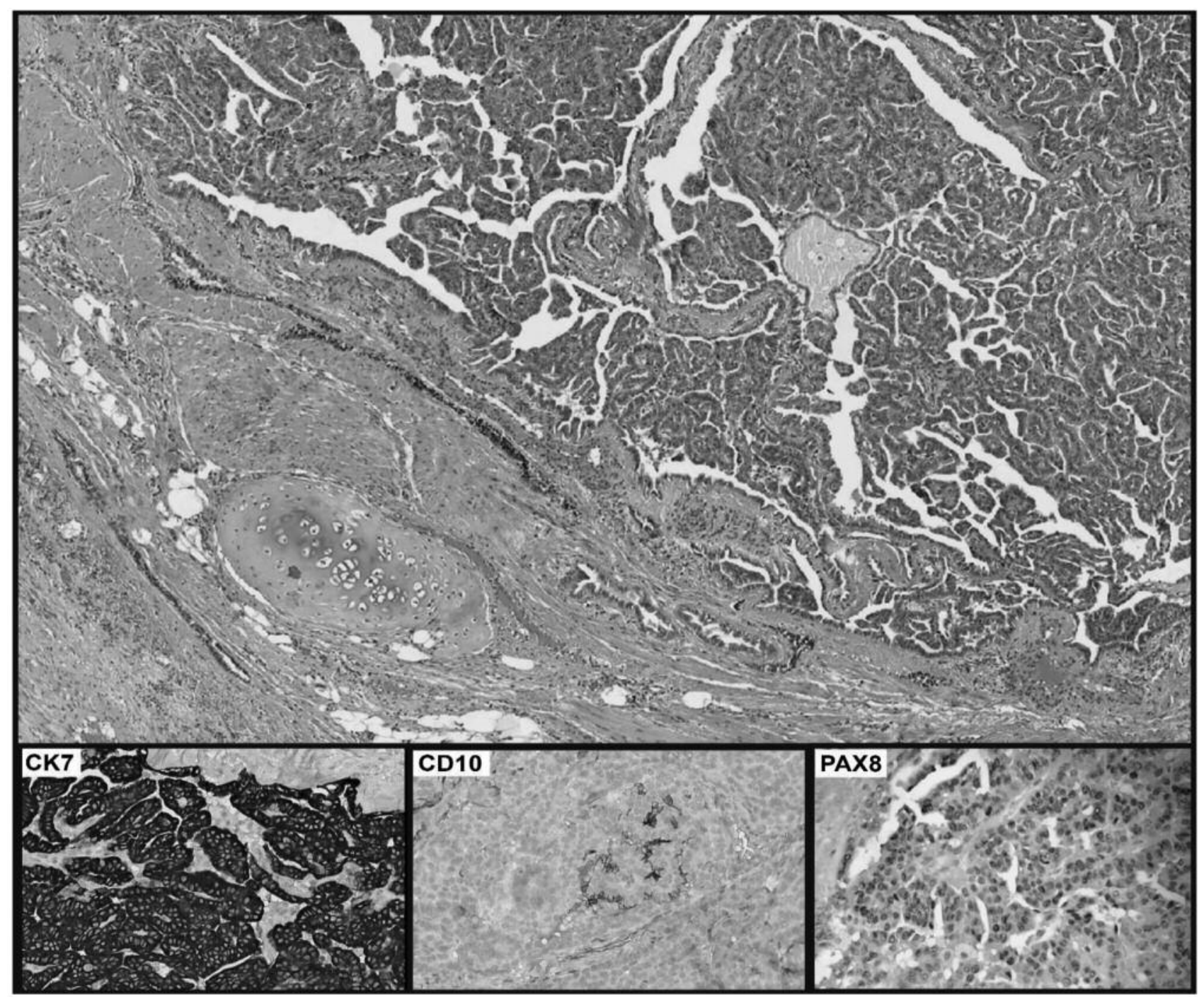

Figure 2. Type 2 papillary renal cell carcinoma within a mature cystic teratoma of the ovary. A type 2 papillary renal cell carcinoma arising in a mature cystic teratoma: papillary projections occupy the lumen of the cyst cavity, while fragments of cartilage are present inside the cyst wall. Immunohistochemical analysis showed strong positivity for CK7 and mild positivity for CD10 and PAX8, suggesting a renal lineage.

Our patient with type 2 papillary renal carcinoma within an MCT of the ovary is free of disease 16 months after unilateral salpingo-oophorectomy. To our best knowledge, this is the first case of such malignancy reported in the literature.

About $15 \%$ of MCTs contain thyroid tissue, but the term struma ovarii must be used only when thyroid tissue is the predominant element (39). Struma ovarii accounts for $2-5 \%$ of all MCTs, malignant transformation occurs in $5-10 \%$ of struma ovarii, and metastases develop in 5-23\% of malignant struma ovarii $(12,13,15,39-41)$. Clinical hyperthyroidism has been observed in $5-8 \%$ of the cases $(12,13,39)$.

The surgical management ranges from bilateral salpingooophorectomy with total hysterectomy, omentectomy and retroperitoneal node dissection to unilateral salpingooophorectomy especially in patients who have no evidence of extra-ovarian disease and who wish to preserve fertility $(12,15,42,43)$. Abdominal surgery should be followed by thyroidectomy and $\mathrm{I}^{131}$ ablation, since thyroidectomy can enable follow-up with serum thyroglobulin assay and radioiodine scintigraphy and $\mathrm{I}^{131}$ treatment can prevent local and distant recurrence $(12,15,44)$. Thyroidectomy and $I^{131}$ ablation are strictly recommended as first-line treatment in cases with extra-ovarian spread of disease $(12,15,45)$.

Our patient with papillary thyroid carcinoma within a struma ovarii had previously undergone thyroidectomy followed by $\mathrm{I}^{131}$ ablation for a papillary carcinoma of the 


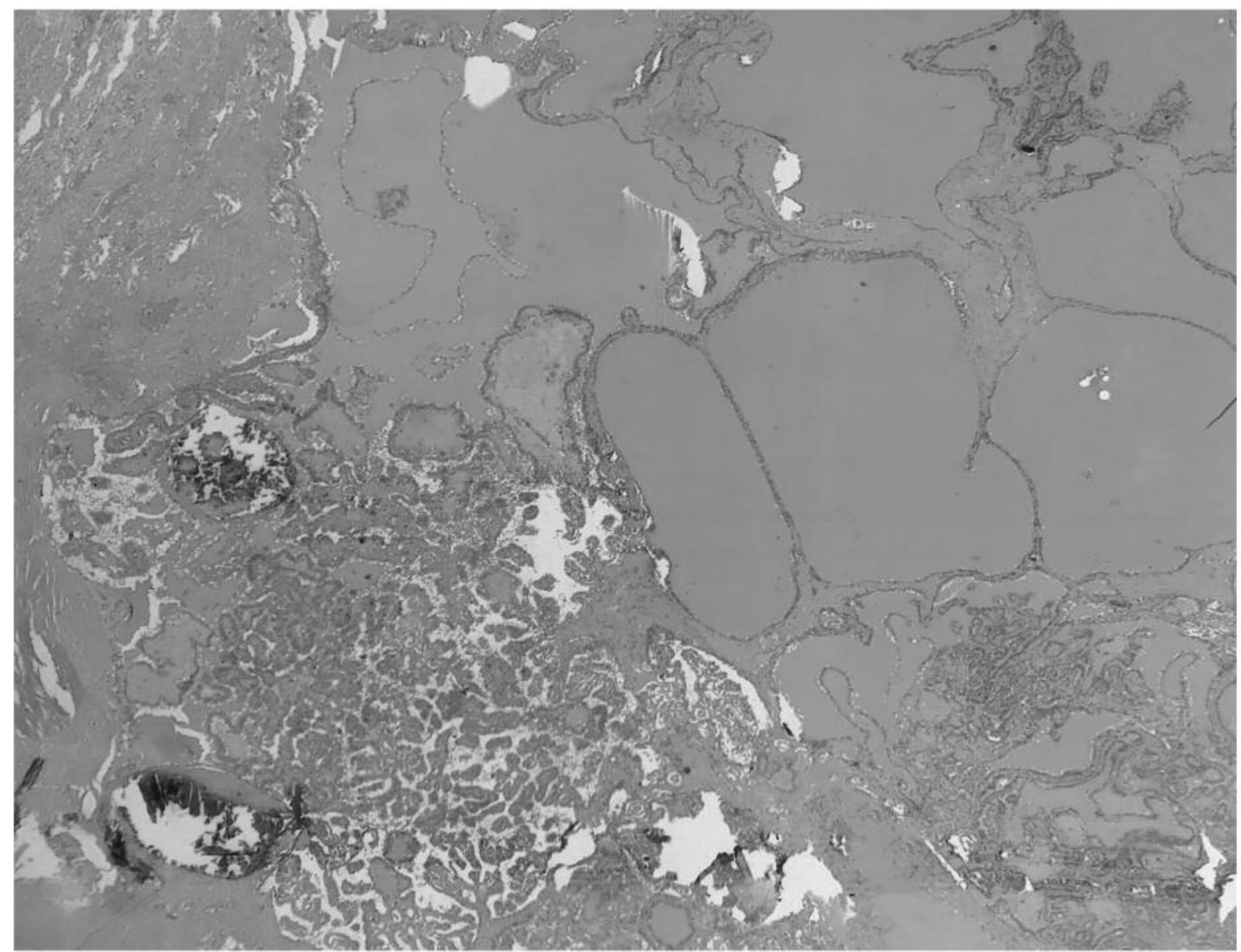

Figure 3. Papillary thyroid carcinoma within a struma ovarii. Papillary thyroid carcinoma arising in a struma ovarii; the carcinoma is located in the lower left of the image, and it is surrounded by apparently normal thyroid follicles.

thyroid gland. Radioiodine scintigraphy, performed for the detection of elevated serum thyroglobulin levels, showed an intense $\mathrm{I}^{131}$ uptake in the right pelvis and CT scan revealed a complex mass involving the right ovary. The patient underwent right salpingo-oophorectomy and the definitive histologic examination showed a small papillary thyroid carcinoma within a struma ovarii. The presence of the latter excluded the hypothesis of an ovarian metastasis from the primary thyroid neoplasia. The patient is free of disease 52 months after surgery.

Malignant transformation of an MCT of the ovary is a rare, but not exceptional event, which usually presents like an incidental pathologic finding. Prospective randomized trials on the surgical and postoperative treatment cannot be planned because of the rarity of these malignancies. However, a large international centralized database could maximize clinicians' knowledge in order to better define treatment guidelines $(1,39)$.

\section{Conflicts of Interest}

The Authors have no conflicts of interest regarding this study.

\section{References}

1 Hackethal A, Brueggmann D, Bohlmann MK, Franke FE, Tinneberg HR and Münstedt K: Squamous-cell carcinoma in mature cystic teratoma of the ovary: systematic review and analysis of published data. Lancet Oncol 9: 1173-1180, 2008.

2 Goudeli C, Varytimiadi A, Koufopoulos N, Syrios J and Terzakis $\mathrm{E}$ : An ovarian mature cystic teratoma evolving in squamous cell carcinoma: A case report and review of the literature. Gynecol Oncol Rep 19: 27-30, 2016.

3 Sinha A and Ewies AA: Ovarian mature cystic teratoma: challenges of surgical management. Obstet Gynecol Int 2016: 2390178, 2016

4 Rim SY, Kim SM and Choi HS: Malignant transformation of ovarian mature cystic teratoma. Int J Gynecol Cancer 16: 140144, 2006. 
5 Dos Santos L, Mok E, Iasonos A, Park K, Soslow RA, Aghajanian C, Alektiar K, Barakat RR and Abu-Rustum NR: Squamous cell carcinoma arising in mature cystic teratoma of the ovary: a case series and review of the literature. Gynecol Oncol 105: 321-324, 2007.

6 Ulker V, Numanoglu C, Akbayir O, Akyol A, Tuncel A, Akca A and Aydin O: Malignant transformation arising from mature cystic teratoma of the ovary: a report of six cases. J Obstet Gynaecol Res 38: 849-853, 2012.

7 Oranratanaphan S and Khemapech N: Characteristics and treatment outcomes of patients with malignant transformation arising from mature cystic teratoma of the ovary: experience at a single institution. Asian Pac J Cancer Prev 14: 4693-4697, 2013.

8 Desouki MM, Fadare O, Chamberlain BK, Shakir N and Kanbour-Shakir A: Malignancy associated with ovarian teratomas: frequency, histotypes, and diagnostic accuracy of intraoperative consultation. Ann Diagn Pathol 19: 103-106, 2015.

9 Black JD, Roque DM, Pasternak MC, Buza N, Rutherford TJ, Schwartz PE, McCarthy S and Ratner E: A series of malignant ovarian cancers arising from within a mature cystic teratoma: a single institution experience. Int J Gynecol Cancer 25: 792-797, 2015.

10 Trabzonlu L, Durmaz G, Vural C, Muezzinoglu B and Corakci A: Malignant tumors associated with ovarian mature teratoma: A single institution experience. Pathol Res Pract 213: 518-521, 2017.

11 Yahata T, Kawasaki T, Serikawa T, Suzuki M and Tanaka K: Adenocarcinoma arising from respiratory ciliated epithelium in benign cystic teratoma of the ovary: a case report with analyzes of the CT, MRI, and pathological findings. J Obstet Gynaecol Res 34: 408-412, 2008.

12 DeSimone CP, Lele SM and Modesitt SC: Malignant struma ovarii: a case report and analysis of cases reported in the literature with focus on survival and $\mathrm{I}^{131}$ therapy. Gynecol Oncol 89: 543-548, 2003.

13 Makani S, Kim W and Gaba AR: Struma ovarii with a focus of papillary thyroid cancer: a case report and review of the literature. Gynecol Oncol 94: 835-839, 2004.

14 Roth LM, Miller AW 3rd and Talerman A: Typical thyroid-type carcinoma arising in struma ovarii: a report of 4 cases and review of the literature. Int J Gynecol Pathol 27: 496-506, 2008.

15 Kumar SS, Rema P, R AK and Varghese BT: Thyroid type papillary carcinoma arising in a mature teratoma. Indian J Surg Oncol 5: 168-170, 2014.

16 Chen RJ, Chen KY, Chang TC, Sheu BC, Chow SN and Huang SC: Prognosis and treatment of squamous cell carcinoma from a mature cystic teratoma of the ovary. Formos Med Assoc 107: 857-868, 2008.

17 Abhilasha N, Bafna UD, Pallavi VR, Rathod PS and Krishnappa $\mathrm{S}$ : A review of squamous cell carcinoma arising in mature cystic teratoma of the ovary. Indian J Cancer 53: 612-614, 2016.

18 Kido A, Togashi K, Konishi I, Kataoka ML, Koyama T, Ueda H, Fujii $\mathrm{S}$ and Konishi J: Dermoid cysts of the ovary with malignant transformation: MR appearance. AJR Am J Roentgenol 172: 445-449, 1999.

19 Emoto M, Obama H, Horiuchi S, Miyakawa $\mathrm{T}$ and Kawarabayashi T: Transvaginal color Doppler ultrasonic characterization of benign and malignant ovarian cystic teratomas and comparison with serum squamous cell carcinoma antigen. Cancer 88: 2298-2304, 2000.

20 Park SB, Kim JK, Kim KR and Cho KS: Preoperative diagnosis of mature cystic teratoma with malignant transformation: analysis of imaging findings and clinical and laboratory data. Arch Gynecol Obstet 275: 25-31, 2007.

21 Patni R: Squamous cell carcinoma arising in mature cystic teratoma of ovary. J Midlife Health 5: 195-197, 2014.

22 Dujardin MI, Sekhri P and Turnbull LW: Struma ovarii: role of imaging? Insights Imaging 5: 41-51, 2014.

23 Gil R, Cunha TM and Rolim I: Mature cystic teratoma with high proportion of solid thyroid tissue: a controversial case with unusual imaging findings. J Radiol Case Rep 11: 20-30, 2017.

24 Middelbeek RJW, O’Neill BT, Nishino M and Pallotta JA: Concurrent intrathyroidal thyroid cancer and thyroid cancer in struma ovarii: a case report and literature review. J Endocr Soc 23: 396-400, 2017.

25 Chiang AJ, La V, Peng J, Yu KJ and Teng NN: Squamous cell carcinoma arising from mature cystic teratoma of the ovary. Int J Gynecol Cancer 21: 466-474, 2011.

26 Tseng CJ, Chou HH, Huang KG, Chang TC, Liang CC, Lai CH, Soong YK, Hsueh S and Pao CC: Squamous cell carcinoma arising in mature cystic teratoma of the ovary. Gynecol Oncol 63: 364-370, 1996.

27 Sakuma M, Otsuki T, Yoshinaga K, Utsunomiya H, Nagase S, Takano T, Niikura H, Ito K, Otomo K, Tase T, Watanabe Y and Yaegashi N: Malignant transformation arising from mature cystic teratoma of the ovary: a retrospective study of 20 cases. Int $\mathbf{J}$ Gynecol Cancer 20: 766-771, 2010.

28 Kurtz JE, Jaeck D, Maloisel F, Jung GM, Chenard MP and Dufour P: Combined modality treatment for malignant transformation of a benign ovarian teratoma. Gynecol Oncol 73: 319-321, 1999.

29 Yoshida K, Kajiyama H, Utsumi F, Mitsui H, Shibata K and Kikkawa F: Radiotherapy for persistent malignant transformation from mature cystic teratoma of the ovary. $\mathrm{J}$ Obstet Gynaecol Res 42: 584-588, 2016.

30 Reed NS, Gomez-Garcia E, Gallardo-Rincon D, Barrette B, Baumann K, Friedlander M, Kichenadasse G, Kim JW, Lorusso D, Mirza MR and Ray-Coquard I: Gynecologic Cancer InterGroup (GCIG) consensus review for carcinoid tumors of the ovary. Int J Gynecol Cancer 24: S35-41, 2014.

31 Verguts J, Amant F, Moerman P and Vergote I: HPV induced ovarian squamous cell carcinoma: case report and review of the literature. Arch Gynecol Obstet 276: 285-289, 2007.

32 Liu LC, Huang RL, Lin YC, Lai HC, Su HY, Chang FW and Yu $\mathrm{MH}$ : Squamous cell carcinoma arising from an ovarian teratoma related to human papillomavirus infection: using a PCR-based reverse-blot assay. Taiwan J Obstet Gynecol 50: 543-545, 2011.

33 Araujo IB, Pinheiro MV, Zanvettor PH, Studart EJ, Filho DF and Coupland SE: High frequency of malignant transformation of ovarian mature teratoma into squamous cell carcinoma in young patients in Northeast Brazil. Int J Gynecol Pathol 35: 176-184, 2016.

34 Chiang AJ, Chen DR, Cheng JT and Chang TH: Detection of human papillomavirus in squamous cell carcinoma arising from dermoid cysts. Taiwan J Obstet Gynecol 54: 559-566, 2015.

35 Courthod G, Tucci M, Di Maio M and Scagliotti GV: Papillary renal cell carcinoma: A review of the current therapeutic landscape. Crit Rev Oncol Hematol 96: 100-112, 2015. 
36 Delahunt B, Eble JN, McCredie MR, Bethwaite PB, Stewart JH and Bilous AM: Morphologic typing of papillary renal cell carcinoma: comparison of growth kinetics and patient survival in 66 cases. Hum Pathol 32: 590, 2001.

37 Pignot G, Elie C, Conquy S, Vieillefond A, Flam T, Zerbib M, Debré B and Amsellem-Ouazana D: Survival analysis of 130 patients with papillary renal cell carcinoma: prognostic utility of type 1 and type 2 subclassification. Urology 69: 230-235, 2007.

38 Motzer RJ, Jonasch E, Agarwal N, Bhayani S, Bro WP, Chang SS, Choueiri TK, Costello BA, Derweesh IH, Fishman M, Gallagher TH, Gore JL, Hancock SL, Harrison MR, Kim W, Kyriakopoulos C, LaGrange C, Lam ET, Lau C, Michaelson MD, Olencki T, Pierorazio PM, Plimack ER, Redman BG Shuch B, Somer B, Sonpavde G, Sosman J, Dwyer M and Kumar R: Kidney Cancer, Version 2.2017, NCCN clinical practice guidelines in oncology. J Natl Compr Canc Netw 15: 804-834, 2017.

39 Dardik RB, Dardik M, Westra W and Montz FJ: Malignant struma ovarii: two case reports and a review of the literature. Gynecol Oncol 73: 447-451,1999.

40 Matsuda K, Maehama T and Kanazawa K: Malignant struma ovarii with thyrotoxicosis. Gynecol Oncol 82: 575-577, 2001.

41 Gobitti C, Sindoni A, Bampo C, Baresic T, Giorda G, Alessandrini L, Canzonieri V, Franchin G and Borsatti E: Malignant struma ovarii harboring a unique NRAS mutation: case report and review of the literature. Hormones (Athens) 16: 322-327, 2017.
42 Goffredo P, Sawka AM, Pura J, Adam MA, Roman SA and Sosa JA: Malignant struma ovarii: a population-level analysis of a large series of 68 patients. Thyroid 25: 211-215, 2015.

43 Zhu Y, Wang C, Zhang GN, Shi Y, Xu SQ, Jia SJ and He R: Papillary thyroid cancer located in malignant struma ovarii with omentum metastasis: a case report and review of the literature. World J Surg Oncol 14: 17, 2016.

44 Kostoglou-Athanassiou I, Lekka-Katsouli I, Gogou L, Papagrigoriou L, Chatonides I and Kaldrymides P: Malignant struma ovarii: report of a case and review of the literature. Horm Res 58: 34-38, 2002

45 Zekri JM, Manifold IH and Wadsley JC: Metastatic struma ovarii: late presentation, unusal features and multiple radioactive iodine treatments. Clinical Oncol (R Coll Radiol) 18: 768-772, 2006.
Received April 5, 2018

Revised May 8, 2018

Accepted May 9, 2018 